Bradleya 30/2012

pages $61-64$

\title{
South Africa's ongoing Opuntia Mill. (Cactaceae) problem: the case of Opuntia tomentosa Salm-Dyck
}

\author{
Gideon F. Smith ${ }^{1}$ and Estrela Figueiredo 2 \\ ${ }^{1}$ Office of the Chief Director: Biosystematics Research and Biodiversity Collections, South African National Bio- \\ diversity Institute, Private Bag X101, Pretoria 0001 South Africa / Acocks Chair, Schweickerdt Herbarium, De- \\ partment of Botany, University of Pretoria, Pretoria, 0002 South Africa / Centre for Functional Ecology, \\ Departamento de Ciências da Vida, Universidade de Coimbra, 3001-455 Coimbra, Portugal \\ (email: g.smith@sanbi.org.za). \\ 2 Department of Botany, P.O.Box 77000, Nelson Mandela Metropolitan University, Port Elizabeth, 6031 \\ South Africa / Centre for Functional Ecology, Departamento de Ciências da Vida, Universidade de Coimbra, \\ 3001-455 Coimbra, Portugal (email: estrelafigueiredo@ hotmail.com).
}

Summary: Opuntia tomentosa Salm-Dyck is recorded as having become naturalised in the Eastern Cape Province of South Africa. A description and illustrations of the species in South Africa are provided, along with a discussion of the characters that distinguish it from Opuntia ficusindica (L.) Mill., the only other tree-like opuntia that has become naturalised in the country.

Zusammenfassung: Opuntia tomentosa SalmDyck wird als verwildert für die Eastern CapeProvinz von Südafrika nachgewiesen. Es wird eine Beschreibung mit Abbildungen des Taxons in Südafrika gegeben, zusammen mit einer Diskussion der Merkmale, die es von der einzigen weiteren, im Land verwilderten baumförmigen Opuntienart Opuntia ficus-indica (L.) Mill. unterscheiden.

\section{Introduction}

A comprehensive survey indicated that, until recently, 12 species (13 taxa) of Opuntia were accepted as naturalised in South Africa (Smith et al., 2011; Walters et al., 2011). A further species, Opuntia tomentosa Salm-Dyck, was recently encountered as established in the Eastern Cape Province, near the small hamlet of Hamburg in close proximity to East London, increasing these numbers to 13 and 14, respectively. The species spreads unaided by humans and covers a small area in the flood plains of the Keiskamma River near the mouth of the river.

Opuntia tomentosa (or Cactus tomentosus) has been known in cultivation in Europe since the beginning of the $17^{\text {th }}$ century, having been depicted by Basilius Besler (1561-1629) in "Hortus
Eystettensis", as one of the plants growing in the garden of the bishop of the diocese of Eichstatt (Rowley, 1997). However, application of the name O. tomentosa Salm-Dyck has been the subject of some controversy following its use by Crook \& Mottram (2001: 113, 2004: 58) for the species commonly known as $O$. pubescens J.C.Wendl. ex Pfeiff. (see Rowley, 1999 and Crook \& Mottram, 2004: 58 for a discussion). Leuenberger (2002: 147) concluded that "...[Opuntia tomentosa] is in long-established use for a Mexican species fitting well the original description of an erect, flatstemmed plant with much larger stem segments than the low growing $O$. pubescens" and commented that from the protologues (SalmReifferscheid-Dyck, 1822) the two names refer to two distinct species. Hunt (2006: 13) and Hunt et al., (2006a: 212) independently arrived at the same conclusion. We therefore consider the name Opuntia tomentosa Salm-Dyck as applicable to the material naturalised in South Africa.

In this paper O. tomentosa is for the first time described as it occurs in South Africa. To facilitate identification, the vegetative and reproductive morphology of the species are illustrated, especially since the comprehensive work of Hunt et al. (2006b) did not carry illustrations of the species. Differences between $O$. tomentosa and O. ficus-indica (L.) Mill., the only other tree-like opuntia naturalised in South Africa, are provided.

\section{Opuntia tomentosa established in South} Africa

A recent fieldtrip to the eastern and central parts of the Eastern Cape Province of South Africa included a survey of the vegetation near Hamburg, 

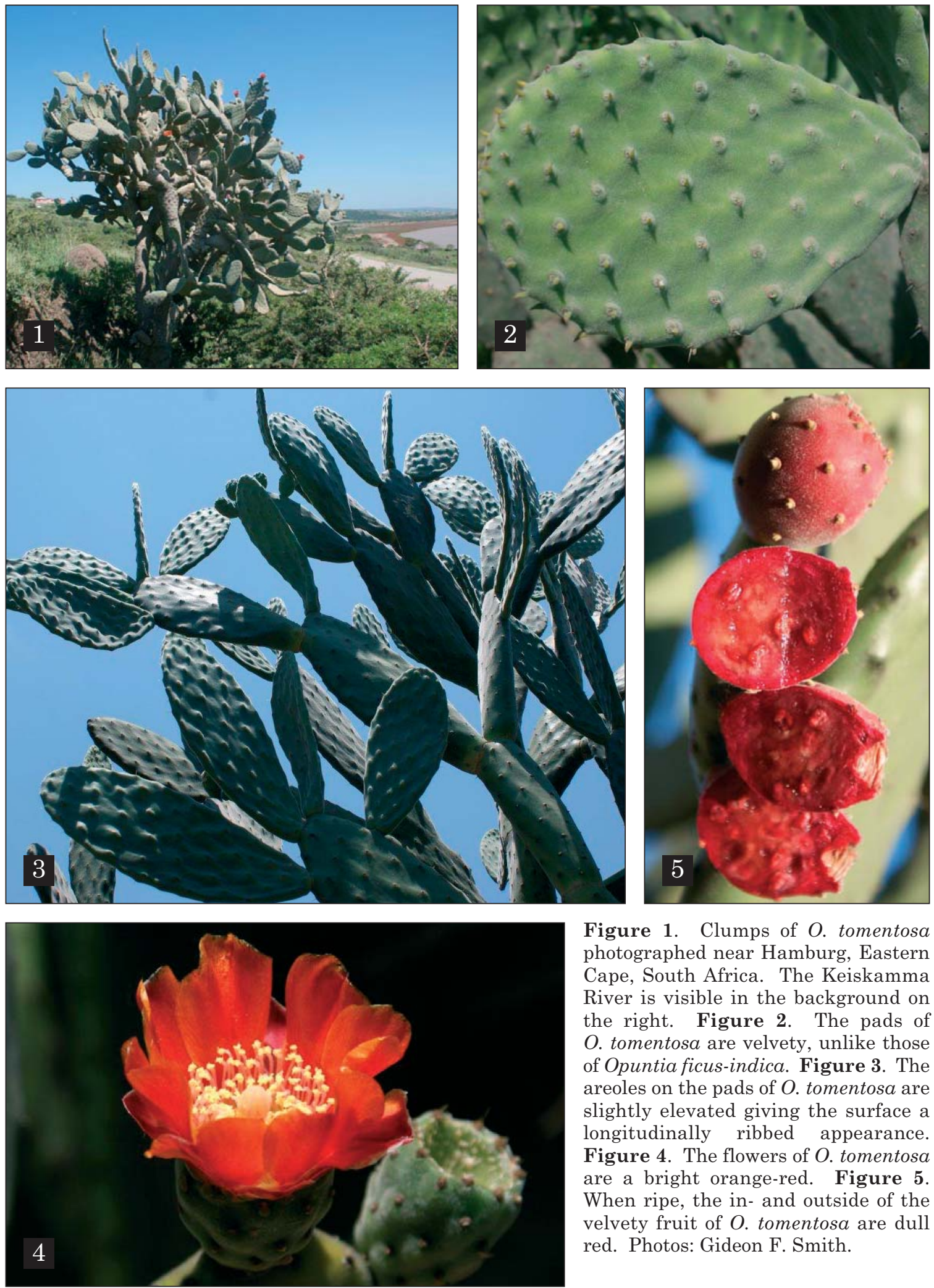

Figure 1. Clumps of $O$. tomentosa photographed near Hamburg, Eastern Cape, South Africa. The Keiskamma River is visible in the background on the right. Figure 2. The pads of $O$. tomentosa are velvety, unlike those of Opuntia ficus-indica. Figure 3. The areoles on the pads of $O$. tomentosa are slightly elevated giving the surface a longitudinally ribbed appearance. Figure 4. The flowers of $O$. tomentosa are a bright orange-red. Figure 5. When ripe, the in- and outside of the velvety fruit of $O$. tomentosa are dull red. Photos: Gideon F. Smith. 
a small coastal town south of East London. The reasonably unspoilt resort - it is hardly a town was established on the mouth of the Keiskamma River and is popular among water sports enthusiasts. Opuntia tomentosa was encountered a few kilometers outside of the hamlet where several mature clumps are dotted around the landscape, straddling the road leading to the residential and recreational area (Figure 1).

Like most species of Opuntia Mill., O. tomentosa is easy to propagate, especially from cuttings. Pads detached at the joint or constriction between segments are simply placed erect in the soil where they are intended to grow. When so treated, these stem sections strike root easily, and grow rapidly into medium-sized to large clump-like trees consisting of a dense network of large, oblong to obovate to assymetrical pads.

It is not known how, when, or for what purpose the plants were introduced into South Africa, nor how they reached Hamburg - there is no plant nursery nearby - but they could have been discarded from domestic town or rural gardens. It did not appear that propagules were washed down the river. Most cacti (and other succulents for that matter) that have become naturalised in South Africa invaded natural vegetation as escapes from gardens (Walters et al., 2011), and it is likely that the ornamental fruits and flowers, as well as its generally 'neater', tree-like appearance made $O$. tomentosa more desirable than O. ficus-indica to be grown as a garden subject. Chromosome counts indicate that it is a polyploid (Pinkava, 2002) and most likely of hybrid origin (Majure et al., 2012). It is therefore not impossible that the material now established in South Africa is a cultivar derived from a single clone, especially in view of how easy it is to propagate by vegetative means.

\section{Distinguishing Opuntia tomentosa from O. ficus-indica}

The most obvious difference between Opuntia tomentosa and $O$. ficus-indica is that the surfaces of the pads of the former have a soft, furry covering reminiscent of velvet fabric (Figure 2). It also tends to be more tree-like and the stems and branches tend to remain erect and do not break off as easily as those of $O$. ficus-indica, which tends to form tree-like shrubs. The areoles of O. tomentosa are very slightly elevated, especially during periods of water stress, giving the pads a longitudinally ribbed appearance (Figure 3 ), while the areoles of $O$. ficus-indica are mostly flush with the surface of the pads. Plants of $O$. tomentosa take many years to reach flowering maturity, after which delicate, bright orange-red flowers are carried in the summer months (Figure 4). Once O. tomentosa bears fruit there is no mistaking its smaller prickly pears as these are furry and bright red on the in- and outside (Figure 5), unlike those of $O$. ficus-indica, which are most commonly light green on both the in- and outside (although some cultivars do have brightly coloured fruit).

It should be pointed out though that, although $O$. tomentosa is easily distinguished from $O$. ficusindica and O. pubescens, other arborescent and large, shrubby opuntias cultivated in Mexico for their edible fruits, might be found in South Africa.

Opuntia tomentosa Salm-Dyck in Obs. bot. 3: 8 (1822). Borg (1963: 83-84); Britton \& Rose (1963: 173-174); Backeberg (1977: 377); Anderson (2001: 523); Hunt et al. (2006a: 212).

= Cactus tomentosus Link in Enumeratio plantarum horti Regii Botanici Berolensis altera 2: 24 (1822). Although the authority of this name is sometimes cited as '(Salm-Dyck) Link', there is no reference to Salm-Dyck in Link's publication. Link's Enumeratio was published in the same year as Salm-Dyck's Observationes so it is unlikely that he was aware of Salm-Dyck's name.

In the literature the following names have been associated with what we consider constituting O. tomentosa.

- Opuntia hernandezii DC. in Prodromus 3: 474 (1828); Mém. Mus. Hist. Nat. 17: 69, t. 16 (1828). Opuntia tomentosa Salm-Dyck var. hernandezii (DC.) Bravo in Cact. Suc. Mex. 20: 96 (1975).

- Opuntia oblongata J.C.Wendl. ex Pfeiff. in Enumeratio diagnostic cactearum hucusque cognitarum: 161 (1837) and Beschreibung und Synonymik der Cacteen: 180-181 (1837). An earlier reference, Catalogus hortus Herrenhusanus (1835), cited by Pfeiffer for several Wendland names is unknown, therefore these names are considered to be validated by Pfeiffer (Britton \& Rose 1963: 101).

- Opuntia macdougaliana Rose in Britton \& Rose in Smith. Misc. Collect. 50: 516 (1908). Opuntia velutina var. macdougaliana (Rose) Bravo in Cact. Suc. Mex. 17: 119 (1972).

- Opuntia icterica Griffiths in Monatsschr. Kakteenkunde 23: 138 (1913).

- Opuntia spraguei J.G.Ortega in Boletin de Pro-Cultura Regional. Mazatlan 1(13): Fam. Cact. (1930). Opuntia tomentosa Salm-Dyck var. spraguei (J.G.Ortega) Backeb. in Cactaceae (Backeberg) 1: 542 (1958) as 'Spranguei'. $O$. spraguei is accepted by some authorities (e.g. Tropicos).

- Opuntia rileyi J.G.Ortega in Boletin de Pro-Cultura Regional. Mazatlan 1(13): Fam. 
Cact. (1930). Opuntia tomentosa Salm-Dyck var. rileyi (J.G.Ortega) Backeb. in Cactaceae (Backeberg) 1: 542 (1958). O. rileyi is accepted by some authorities (e.g. Tropicos).

- Opuntia sarca Griffiths ex Scheinvar in Phytologia 49: 328 (1981).

- Opuntia tomentosa Salm-Dyck var. herrerae Scheinvar in Phytologia 49: 332 (1981).

Much-branched, tree-like succulent perennial, erect, 3.0-6.0 m tall. Stem segments (pads) dull to deep green, asymmetrically oblong to oval-shaped, $15.0-30.0 \times 12.0-16.0 \mathrm{~cm}$. Areoles prominent, slightly raised, round, widely dispersed on pads. Needle-like spines often absent, sometimes a single short to medium-long, straight, awl-shaped one present on an areole. Glochids dense, fine, bristle-like, yellowish, turning greyish. Flowers 40-55 mm long, bright orange-red; petal tips slightly frilly. Fruits obovoid to globose one-celled berry, $3.0-5.0 \mathrm{~cm}$ long, $2.5-4.0 \mathrm{~cm}$ in diameter, fleshy, egg-shaped to globose, dull red, covered with scattered areoles bearing dense clusters of glochids.

Common names: Afrikaans: fluweelturksvy; English: velvet opuntia, a common name also applied to Opuntia velutina F.A.C. Weber; Spanish: nopal de San Gabriel (Anderson, 2001).

Distribution in South Africa: The species is here for the first time recorded from South Africa's Eastern Cape Province. It was found in natural vegetation near the small town of Hamburg. This coastal town falls in the indigenous succulent-rich Albany Centre of Endemism (Van Wyk \& Smith, 2001).

Origin: Mexico, where it is widely cultivated, obscuring its exact origin (Hunt et al., 2006a). Anderson (2001) also records the species for Guatemala.

\section{Acknowledgement}

We are grateful to an anonymous referee for commenting on and improving the manuscript. Obscure literature was kindly supplied by Colin C. Walker from his personal library.

\section{References}

Anderson, E.F. (2001). The cactus family. Timber Press, Portland, Oregon.

Backeberg, C. (1977). Cactus lexicon. Enumeratio diagnostica Cactacearum. Blandford Press, Poole, Dorset.

Borg, J. (1963). Cacti. A gardener's handbook for their identification and cultivation. [Reissue of the $3^{\text {rd }}$ ed., first published in 1959.] Blandford Press, London.

Britton, N.L. \& Rose, J.N. (1963). The Cactaceae. Descriptions and illustrations of plants of the cactus family. 1. [Facsimile of the 1937 large paper $2^{\text {nd }}$ ed.] Dover Publications, Inc., New York.

Crook, R. \& Mottram, R. (2001). Opuntia index. Part 7: Nomenclatural note and P-Q. Bradleya 19: 91-116.

Crook, R. \& Mottram, R. (2004). Opuntia index. Part 10: T-V. Bradleya 22: 53-76.

HunT, D. (2006). Opuntia. In D. Hunt \& N. TAYLOR (eds.) Notulae Systematicae Lexicon Cactacearum Spectantes VII. Cact. Syst. Init. 21: 12-13.

Hunt, D., Taylor, N. \& Charles, G. (eds.) (2006a). The new cactus lexicon. Text. dh books, Milborne Port, England.

Hunt, D., Taylor, N. \& Charles, G. (eds.) (2006b). The new cactus lexicon. Atlas of illustrations. dh books, Milborne Port, England.

Leuenberger, B.E. (2002). Humboldt \& Bonpland's Cactaceae in the herbaria at Paris and Berlin. Willdenowia 32: 137-153.

Majure, L.C., Puente, R., Griffith, M.P., Judd, W.S., Soltis, P. \& Soltis, D.E. (2012). Phylogeny of Opuntia s.s. (Cactaceae): clade delineation, geographic origins, and reticulate evolution. Amer. J. Bot. 99: 847-864.

PinkaVA, D. (2002). On the evolution of the continental North American Opuntioideae. Succ. Pl. Res. 6: 59-98.

Rowley, G.D. (1997). A history of succulent plants. Strawberry Press, Mill Valley.

Rowley, G.D. (1999). Salm-Dyck's cactus paintings. Bradleya 17: 1-26.

SALM-REIFFERSCHEID-DYCK, J.M.F.A.H.I. (1822). Observationes botanicae in Horto Dickensi notatae. Fasc. 3. Coloniae [Cologne].

Smith, G.F., Figueiredo, E., BoAtwright, J.S. \& Crouch, N.R. (2011). South Africa's ongoing Opuntia Mill. (Cactaceae) problem: the case of O. microdasys (Lehm.) Pfeiff. Bradleya 29: $73-78$.

VAN WyK, A.E. [BRAAM] \& SMith, G.F. (2001). Regions of floristic endemism in southern Africa. A review with emphasis on succulents. Umdaus Press, Hatfield, South Africa.

Walters, M., Figueiredo, E., Crouch, N.R., WinTER, P.J.D., Smith, G.F., Zimmermann, H.G. \& \& MASHope, B.K. (2011). Naturalized and invasive succulents of southern Africa. ABC Taxa, 11. The Belgian Development Cooperation, Brussels. 